\title{
Petrogenesis of Volcanic Rocks in Alasht, Mazandaran, Iran
}

\author{
Mohammad Ali Arian1, Mohammad Hasan Bazoobandi², Reza Elmi1 \\ ${ }^{1}$ Department of Geology, Faculty of Sciences, North Tehran Branch, Islamic Azad University, Tehran, Iran \\ ${ }^{2}$ Faculty of Science, Shahid Sherafat, University of Farhangian, Tehran, Iran \\ Email: m_bazoobandi@yahoo.com
}

Received 30 January 2016; accepted 6 March 2016; published 9 March 2016

Copyright (C) 2016 by authors and Scientific Research Publishing Inc.

This work is licensed under the Creative Commons Attribution International License (CC BY). http://creativecommons.org/licenses/by/4.0/

c) (†) Open Access

\section{Abstract}

Area studied in this paper is located in the northwest of city of Alasht. The most important varieties of studied rocks are volcanic and semi-volcanic rocks of basic nature. These rocks, which form a distinguishable solid mass on 1:100,000 geological map, belong to Cretaceous period. According to results of petrographic study, rocks of this area include olivine basalt, dolerite, gabbro and microgabbro, and all have almost similar chemical compositions. According to chemistry-based naming process carried out through TAS method, these rocks are entirely basalt and basic and are all products of Sub-alkaline-Tholeiitic magma. According to Harker diagrams, a magmatic differentiation can be observed in all volcanic rocks; furthermore, basaltic magma erupted in this area has undergone an alteration and possibly a crustal contamination. The spider diagrams plotted in this paper show that basic rocks of Alasht area (basalts, andesite basalts, dolerites, gabbros and microgabbros) are all mostly similar to ocean island basalts (OIB). Once field study, sampling and microscopic study stages were complete, ten samples were selected for chemical analysis and were analyzed by XRF method.

\section{Keywords}

Alasht Area, Crustal Contamination, Olivine Basalt, Sub-Alkaline

\section{Introduction}

The study area is located around the city of Savad kuh in Mazandaran province roughly 200 kilometers away from Tehran. This area is positioned between $52^{\circ} 46^{\prime}$ and $52^{\circ} 52^{\prime}$ eastern longitudes and $36^{\circ} 01^{\prime}$ and $36^{\circ} 03^{\prime}$ northern latitudes. It has a total area of about 105 square kilometers, a mountainous terrain, and an average altitude of 1800 meters above sea level. The maximum altitude of the study area is 2882 meters in its minimum altitude is 
1200 meters above sea level. This area is often foggy in summers and its foggy mountainous terrain is a popular tourist attraction. Rock units of this area belong to the Mesozoic era and include units of Triassic, Jurassic and early Cretaceous periods plus an outcrop belonging to Quaternary era (Figure 1).

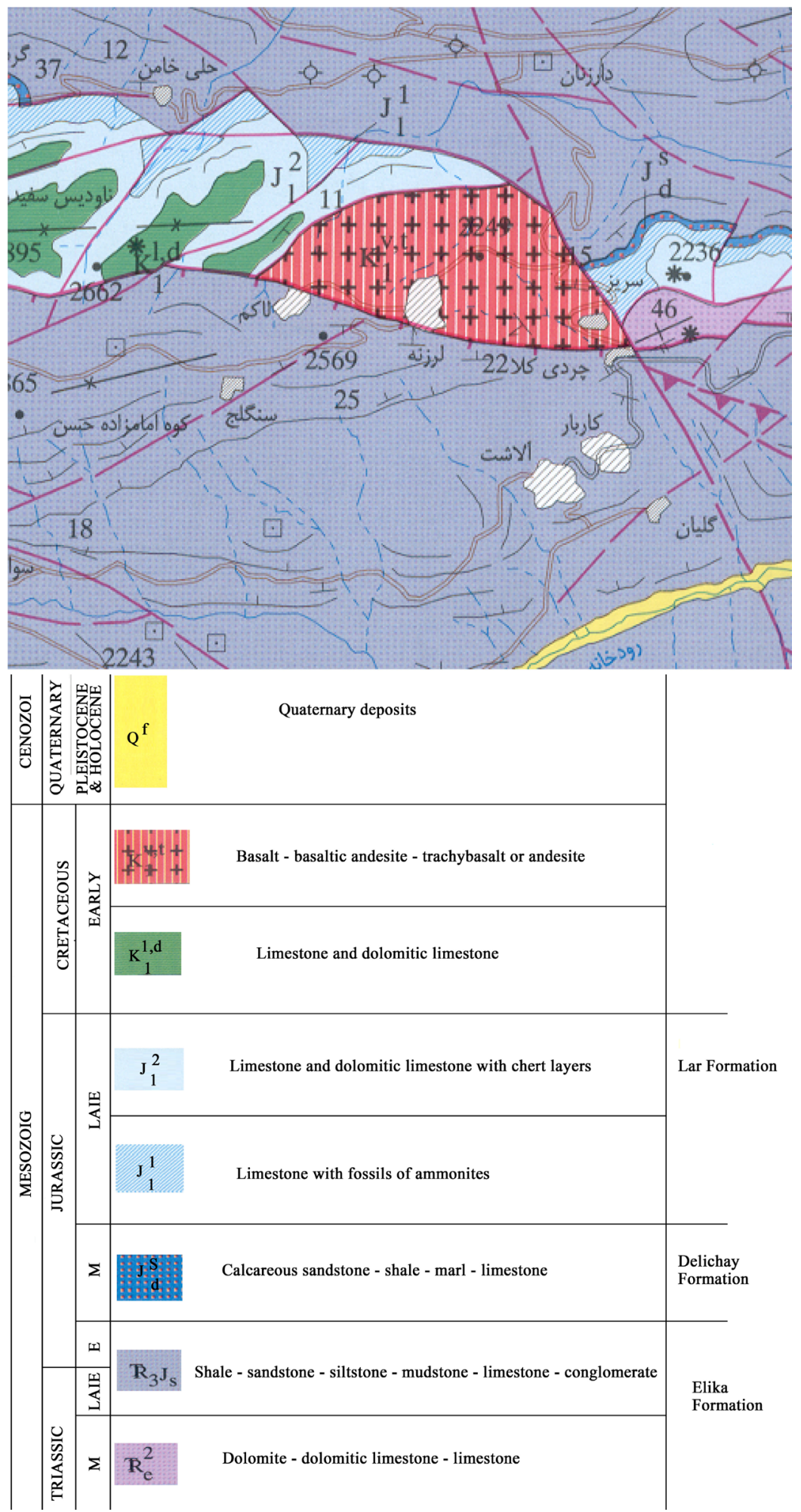

Figure 1. Geological map of the study area, derived from qaemshahr's 1:100,000 geologic sheet. 


\section{Stratigraphy}

This section describes the exposed rock units with accordance to the geological map of the study area.

\subsection{Elika Formation}

This formation has two rock units, but outcrops of the younger one are more frequent in the study area. These units include:

Unit $\mathbb{R}_{e}^{2}$ - This unit consists of gray thickly layered to massive dolomite, limestone, and dolomitic limestone. These outcrops, which are from middle Triassic, can be seen in the eastern side of geological map (Figure 1), and are spread sporadically around northeast of Alasht village and east of Sarin village.

Unit $\mathbb{R}_{3 J_{s}}$ - This unit has the most frequent outcrops in this area, since the entire lower half and a relatively large portion of upper half of the study area belongs to this unit. It is made of alternating layers of shale, sandstone, siltstone, claystone, and quartzitic sandstone, and belongs to late Triassic and early Jurassic.

\subsection{Delichai Formation}

This formation has small outcrops in the east and northwest of study area and is made of calcareous sandstone, shale, marl and layers of limestone. Delichai Formation belongs to Middle Jurassic.

\subsection{Lar Formation}

Within the boundaries of the study area, Lar Formation consists of two units $J_{l}^{1}$ and $J_{l}^{2}$, which both belongs to late Jurassic. Unit $J_{l}^{1}$ is made of dark gray thinly to moderately layered chert and ammonite bearing limestone, and Unit $J_{l}^{2}$ is made of creamy white and light gray thickly layered to massive chert bearing limestone and dolomitic limestone. These units have relatively large outcrops in the northern half and in the east and west of volcanic rocks situated at the study area, and have fault-type borders with the mentioned volcanic rocks.

\subsection{Rock Units Belonging to Early Cretaceous}

Study area contains two units of early Cretaceous.

Unit $K_{1}^{I, d}$ - This unit is made of limestone and dolomitic limestone and has four large outcrops in the west of studied volcanic rocks.

Unit $K_{1}^{V, t}$ - This unit is made of volcanic rocks and this paper is focused on studying the petrogenesis of these igneous rocks. This mass is generally made of basalt, basaltic andesite, trachybasalt, andesite, dolerite and low depth gabbros. The villages of Larzaneh and Sarin are situated on these rocks and the village of Lakum is located at their southwestern side.

\subsection{Quaternary Deposits}

Some Quaternary deposits are observed at the southeastern part of the study area along the Charat River; these include alluvial fans, colluviums, fluvial terraces, residual soils and limnic sediments. The most important fault of this zone is Allahband-Larzaneh fault. The northeastern part of this zone houses Sefidrriz syncline, whose core contains late Cretaceous limestone and dolomitic limestone outcrops; as we move away from the core of the syncline, we arrive at the rock units of Lar Formation, which belong to upper Jurassic.

\section{Petrography}

Petrographic studies conducted on the study area shows the strong presence of basaltic rocks. The entire studied body is made of a single basaltic magma, however as a result of erosion, samples taken from different depths of the mass point out the presence of following rocks:

\subsection{Olivine Basalt}

Most samples are made of this type of rocks. They have a lava-form spread and contain a series of fractures caused by tectonic stress. In some parts, dikes of 30 centimeters to 5 meters thickness are injected into these basalts. These dikes have been created by the same magma that has formed the basalts. The petrographic study has 
identified most of these dikes as dolerite (Figure 2).

According to modal classification, these rocks are named as follows.

Basalt, Basalt \& Andesibasalt, Sub-Alkali Basalts iron and magnesium-rich, Tholeiitic Basalt (Table 1).

Textures of this olivine basalt include porphyritic, microlitic porphyritic, hialoporphyritic, amygdaloidal, ophitic, and glomeroporphyritic. Its matrix ranges from glassy to microcrystalline and microlitic. Phenocrysts including olivine, augite and plagioclase constitute the main minerals of this rock, and the remaining space is filled with fine crystals of augite, magnetite, plagioclase, rutile and sphene (Figure 3).

Glass basalt or Hialobasalts, which have been created by relatively high speed ascension of magma and its rapid solidification after eruption, can be found in the eastern edge of studied igneous mass near the village of Sarin and in western edge of the mass around the village of Lakum. These rocks have been formed from lava flows and contain some olivine basalt. They have a hialoporphyritic texture and their matrix consists of glass, opaque mineral and a small amount of plagioclase microlite, and olivine phenocrysts can also be seen in this matrix. There are also some small pores in the rock that are filled with zeolite or calcite.

\subsection{Dolerite}

Dolerite gets formed when crystallization speed of a basaltic magma at a shallow depth is much higher than its crystallization speed at greater depths; so the difference between dolerite and basalt is in their texture. Dolerites are often can be in the form of dikes. Naturally, flowcharts that name the rocks by their chemical attributes place dolerites in the same category as basalts, since they are only different in texture; so much like olivine basalts, these rocks are named as follows: Basalt, Basalt \& Andesibasalt, Sub-Alkali Basalts iron and magnesium-rich, Tholeiitic Basalt (Table 2).

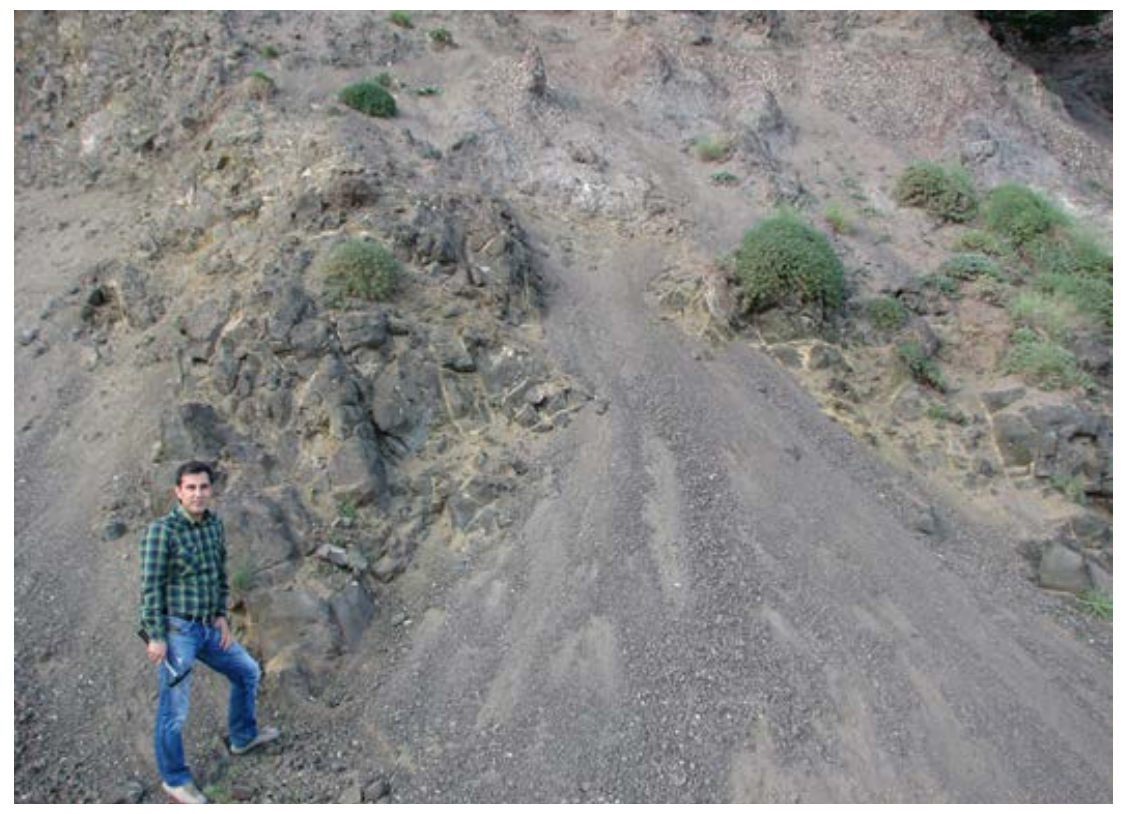

Figure 2. A dike in the study area.

Tabel 1. Classification of alasht igneous rocks.

\begin{tabular}{ll}
\multicolumn{1}{c}{ Naming Basis } & \\
\hline Streckeisen (1976) [1] & Name \\
TAS Cox et al. (1979) [2] & Basalt \\
TAS Middlemost (1994) [3] & Basalt \\
TAS Le Bas et al. (1986) [4] & Basalt \\
Delarochi et al. (1980) [5] & Basalt \& Andes basalt \\
Winchester \& Floyd, (1977) [6] & Sub-Alkali Basalts iron and magnesium-rich \\
Jensen (1976) [7] & Tholeiitic Basalt \\
\hline
\end{tabular}




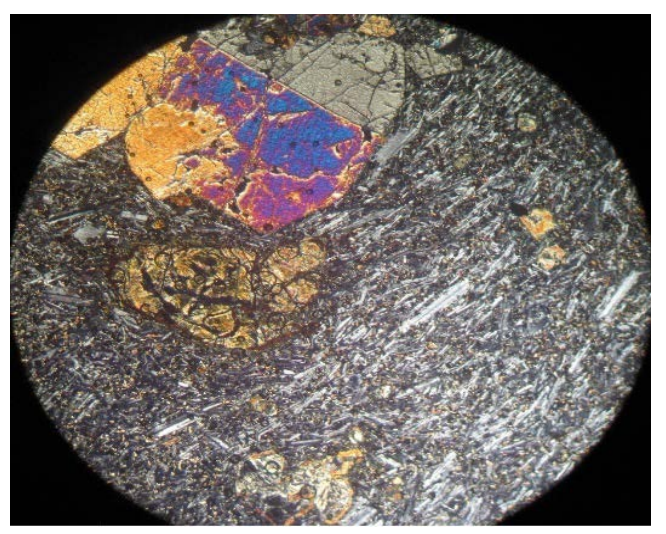

(XPL)

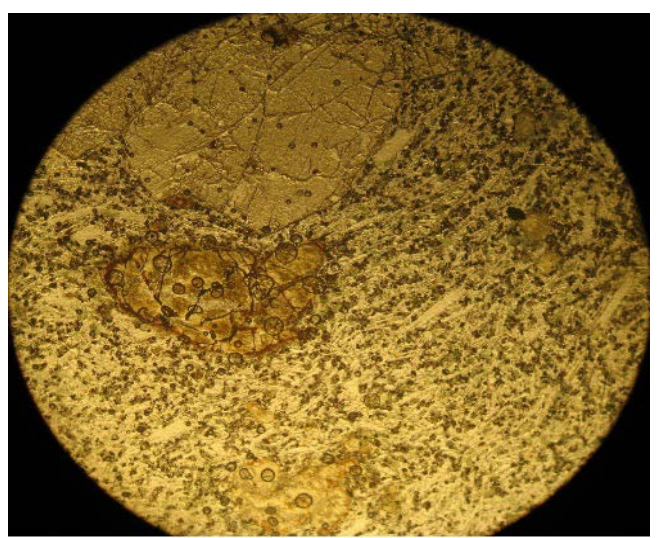

(PPL)

Figure 3. Olivine basalt with microlitic porphyritic texture (4 mm wide field of view).

Table 2. Classification of alasht olivine basalts rocks.

\begin{tabular}{ll}
\multicolumn{1}{c}{ Naming Basis } & \\
\hline Streckeisen (1976) [1] & Basalt \\
TAS Cox et al. (1979) [2] & Basalt \\
TAS Middlemost (1994) [3] & Basalt \\
TAS Le Bas et al. (1986) [4] & Basalt \\
Delarochi et al. (1980) [5] & Basalt \& Andesibasalt \\
Winchester \& Floyd, (1977) [6] & Sub-Alkali Basalts iron and magnesium-rich \\
Jensen (1976) [7] & Tholeiitic Basalt \\
\hline
\end{tabular}

\subsection{Microgabbro}

In this area, erosion has caused the basic magma to have a series of outcrops at different levels, and these outcrops cover an extensive area ranging from the surface to a significant depth. Reasons behind this argument are the chemical similarity of samples and the continuity of volcanic, semi-volcanic, and even deep rocks on the surface. Microgabbro is the product of solidification of basaltic magma at shallow depths and in fact is a subvolcanic to plutonic rock. The following table is the result of chemical analysis performed on samples of this microgabbro (Table 3).

\subsection{Gabbro}

The in-depth crystallization of the same basaltic magma that is the origin of the entire studied mass has led to creation of gabbro. At this stage, two samples of gabbro have been chemically analyzed. Here, gabbros have an intergranular texture and their plagioclase crystals have an average length of $2 \mathrm{~mm}$ and are often automorph and 
to a lesser extent sub-automorph. Amidst plagioclases, there are more or less iddingsitized sub-automorph olivine phenocrysts plus automorph to sub-automorph intact augites. Minor minerals of this rock are rutiles and opaque minerals (Figure 4).

\section{Geochemistry}

Due to fine grain and glassy texture of minerals constituting the volcanic rocks, their volume fraction often cannot be easily determined; as a result, these rocks are commonly named with accordance to their chemical composition. In this paper, samples have also undergone a detailed microscopic study and the obtained results have been found out to be consistent with the results of petrographic studies (Figures 5-7).

Table 3. Classification of alasht microgabbro rocks.

\begin{tabular}{ll}
\multicolumn{1}{c}{ Naming Basis } & \\
\hline Streckeisen (1976) [1] & Name \\
TAS Cox et al. (1979) [2] & Basalt \\
TAS Middlemost (1994) [3] & Basalt \\
TAS Le Bas et al. (1986) [4] & Basalt \\
Delarochi et al. (1980) [5] & Basalt \& Andesibasalt \\
Winchester \& Floyd, (1977) [6] & Sub-Alkali Basalts iron and magnesium-rich \\
Jensen (1976) [7] & Tholeiitic Basalt \\
\hline
\end{tabular}

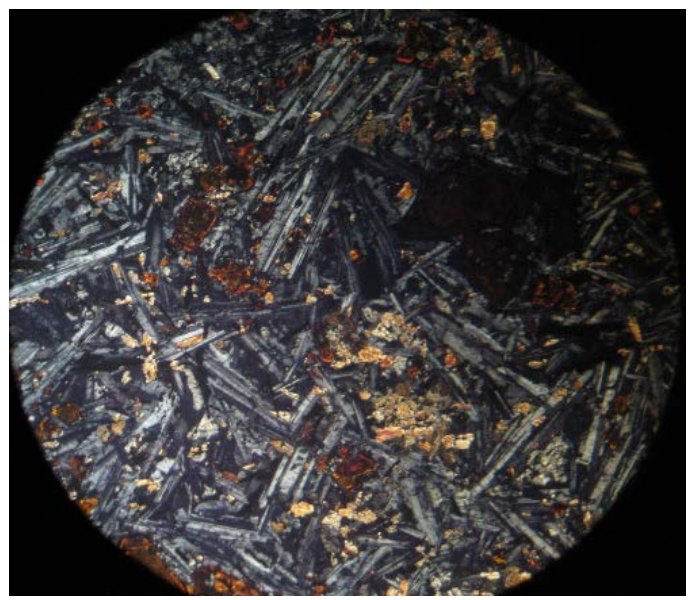

(XPL)

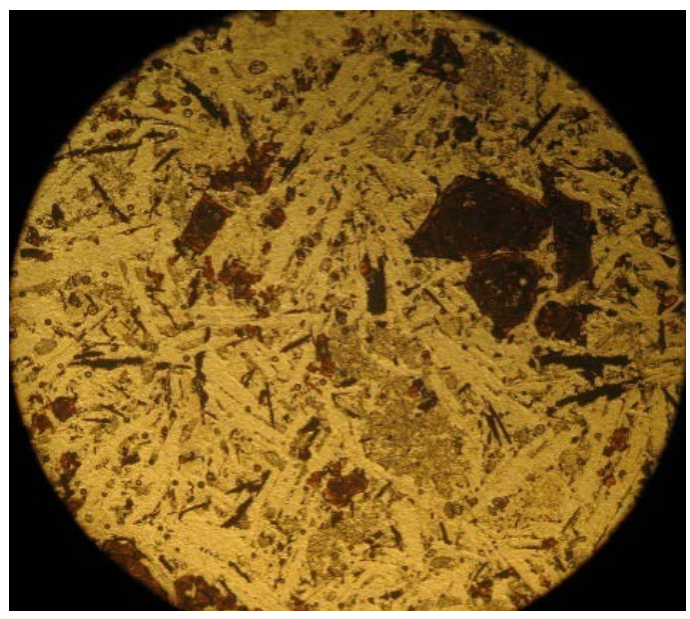

(PPL)

Figure 4. Gabbro with intergranular texture (4 mm wide field of view). 
TAS (Cox et al. 1979)

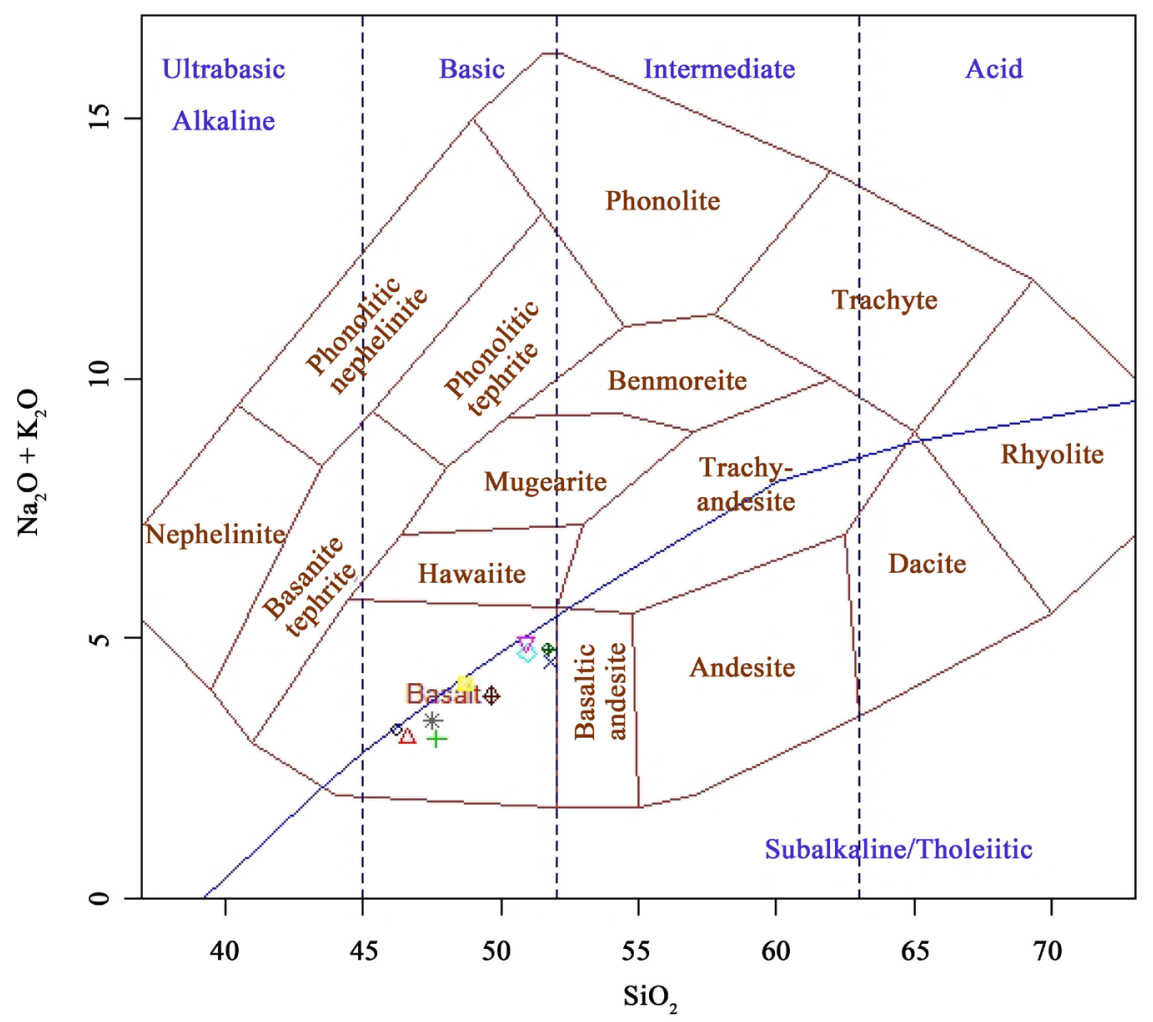

TAS (Le Bas et al. 1986)

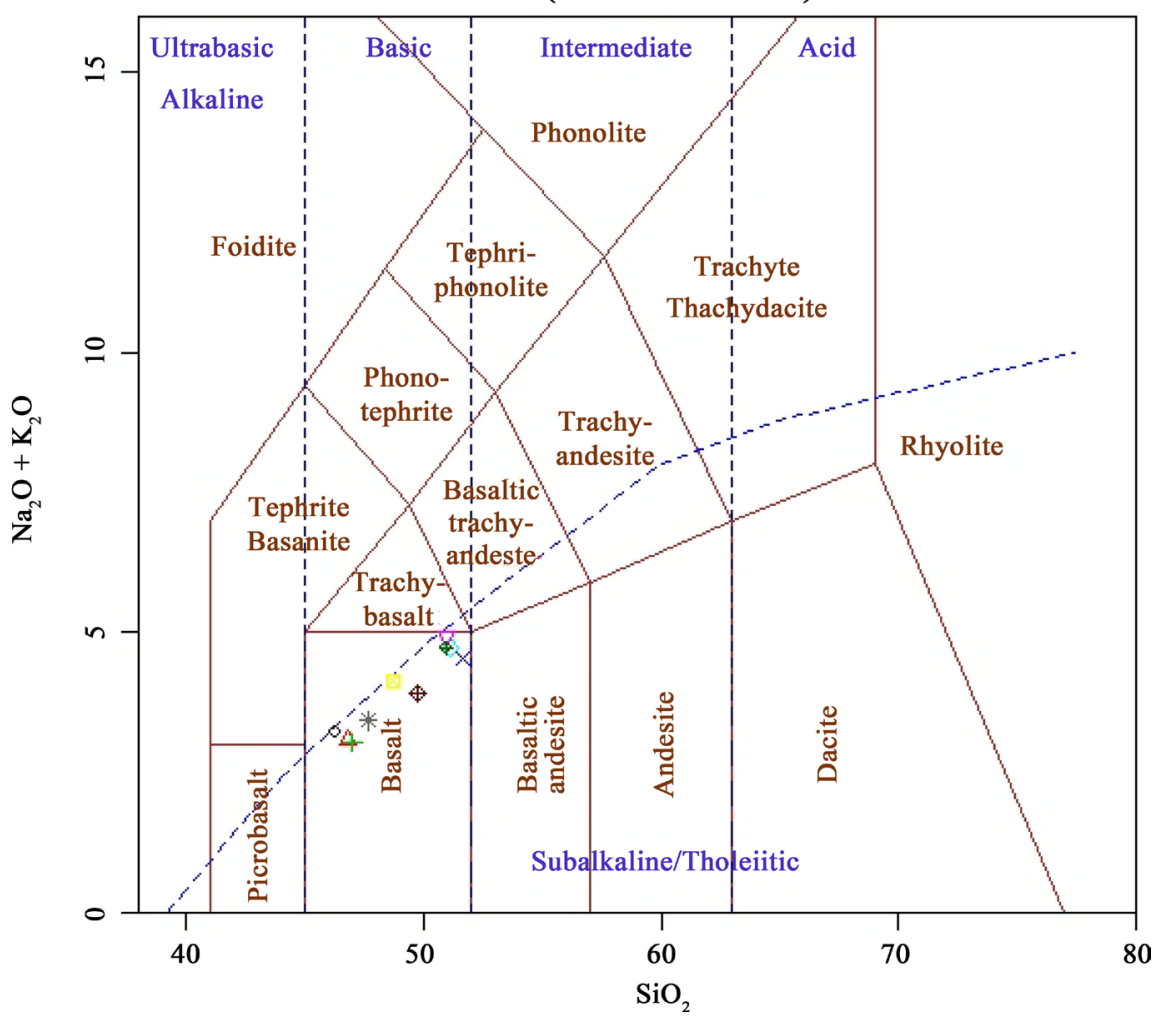

Figure 5. Position of “Alasht” samples on the TAS diagram proposed by (Cox et al. 1979) [2] and (Le Bass et al. 1988) [4]. 
TAS (Middlemost 1994)
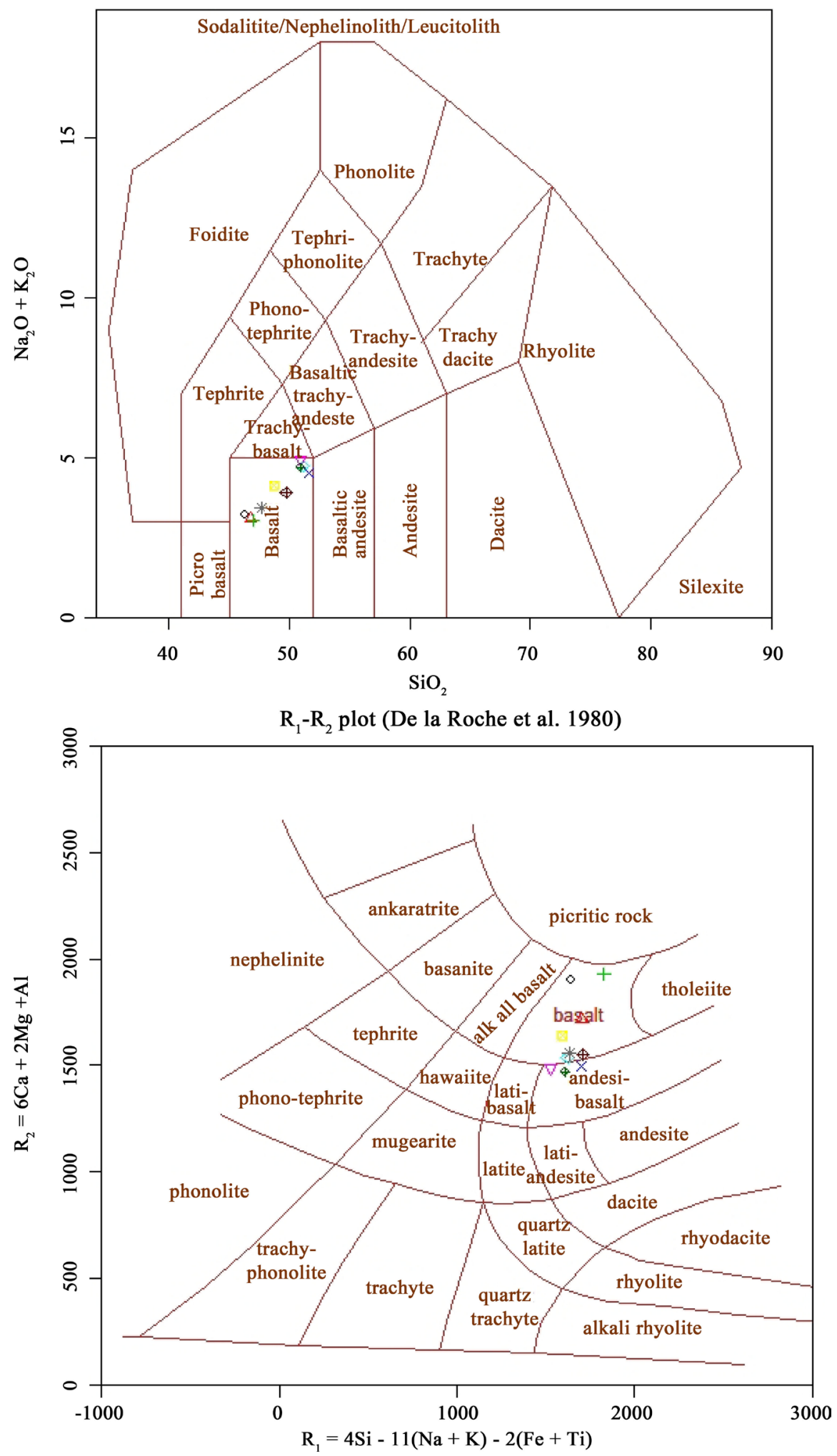

Figure 6. Position of “Alasht” samples on the TAS diagram of (Middlemost. 1994) [3] and R1-R2 plot (De La Roche et al. 1980) [5]. 

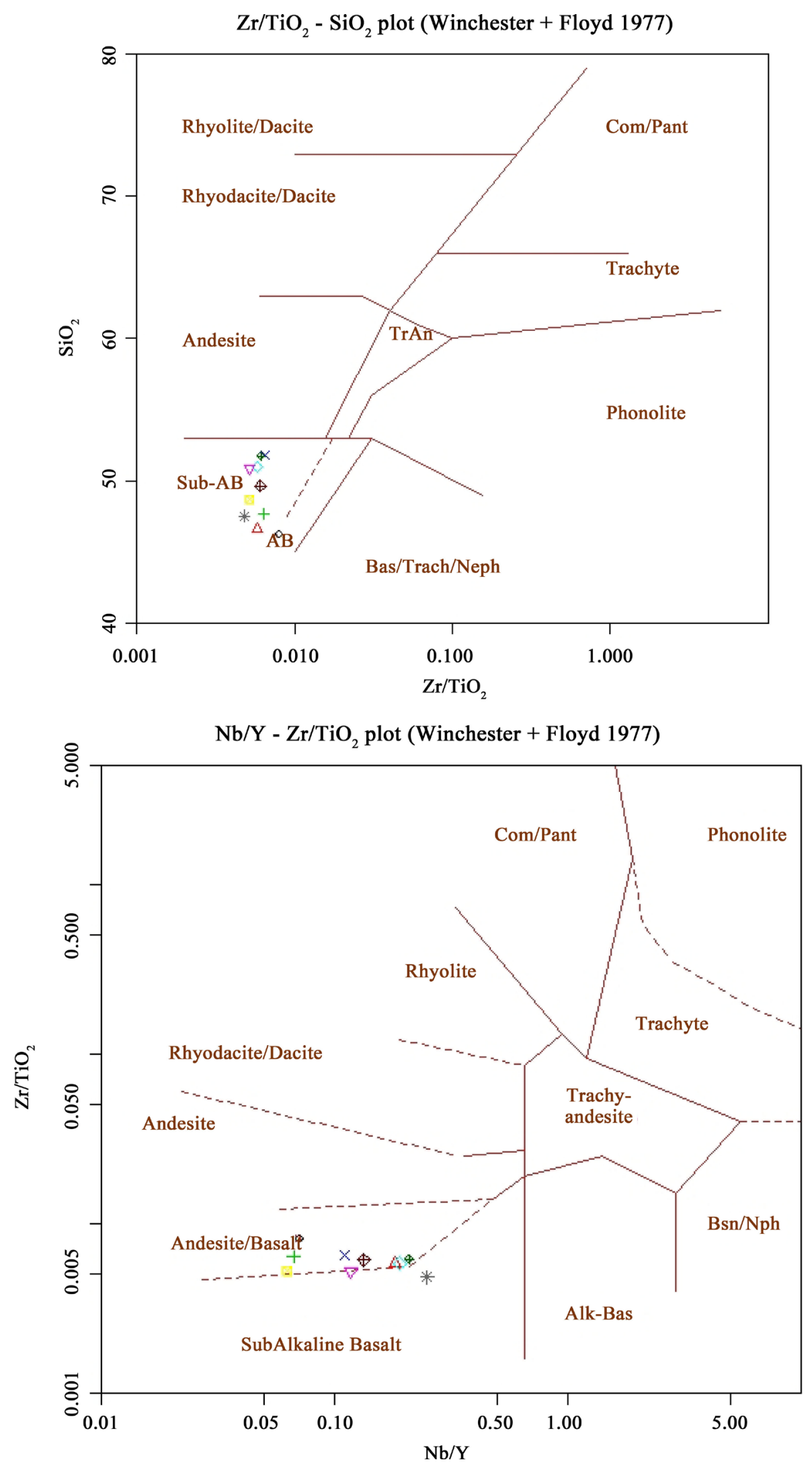

Figure 7. Position of "Alasht” samples on the diagram of (Winchester + Floyd 1977) [6]. 
The frequency of trace elements in Alasht samples has been compared with the frequency of these elements in Chondrites, Ocean Island Basalt (OIB), Normal MORB, Enriched MORB, Primitive Mantle, Lower Crust, Average Crust, Upper Crust, and Primordial Mantle (Figures 8-12).
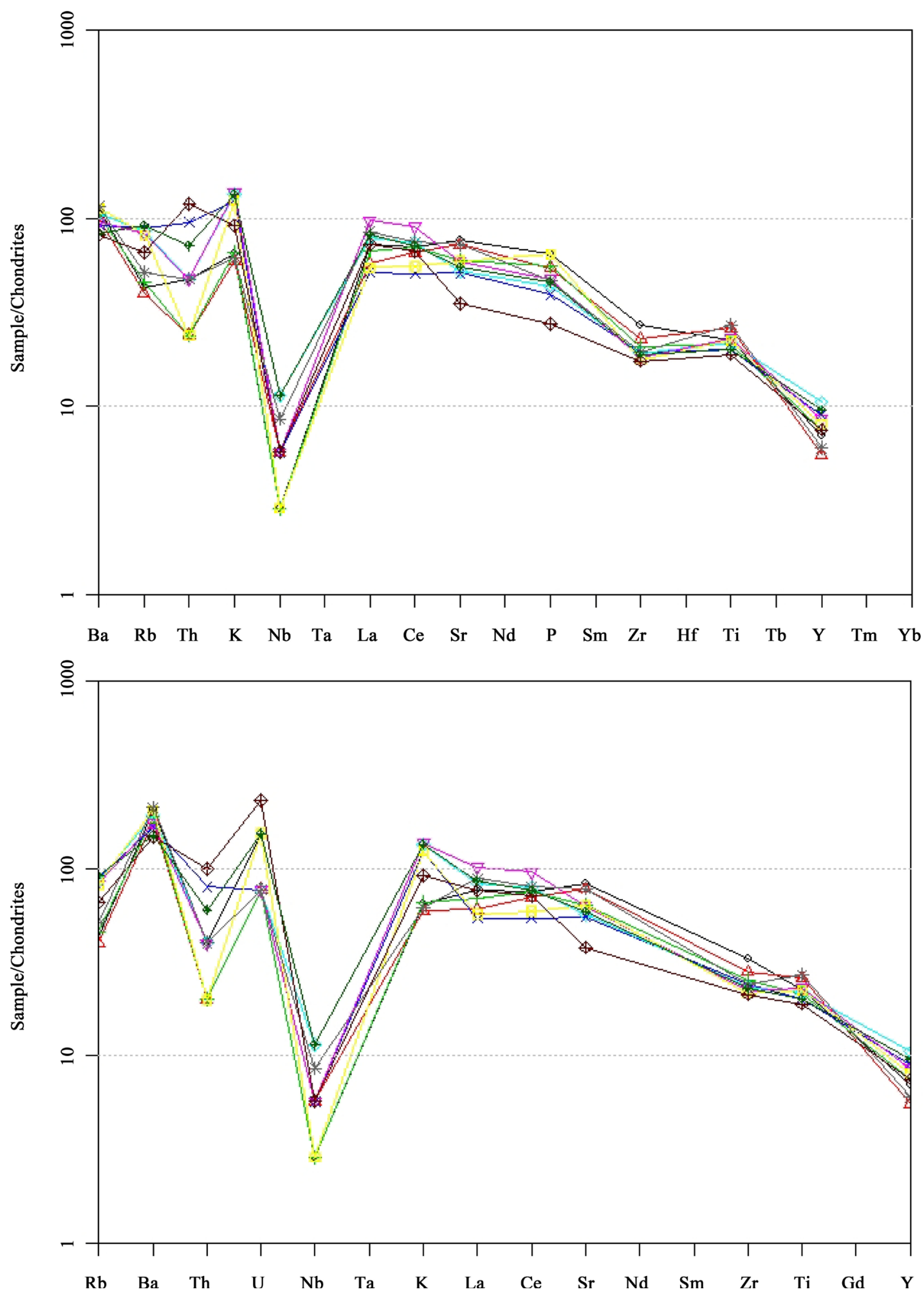

Figure 8. The normalized spider diagram for chondrite. 
M. A. Arian et al.
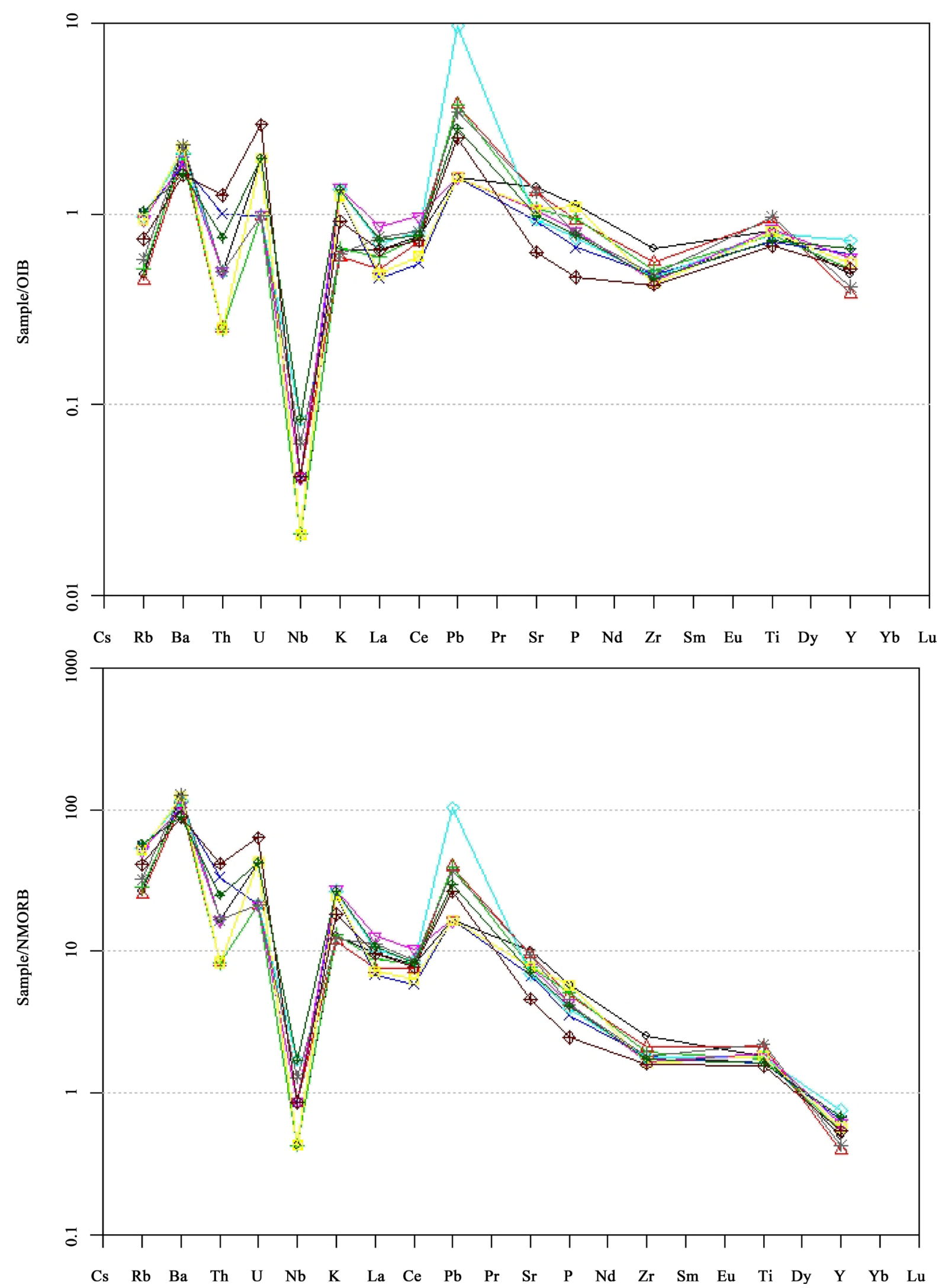

Figure 9. The normalized spider diagram for NMORB and OIB. 

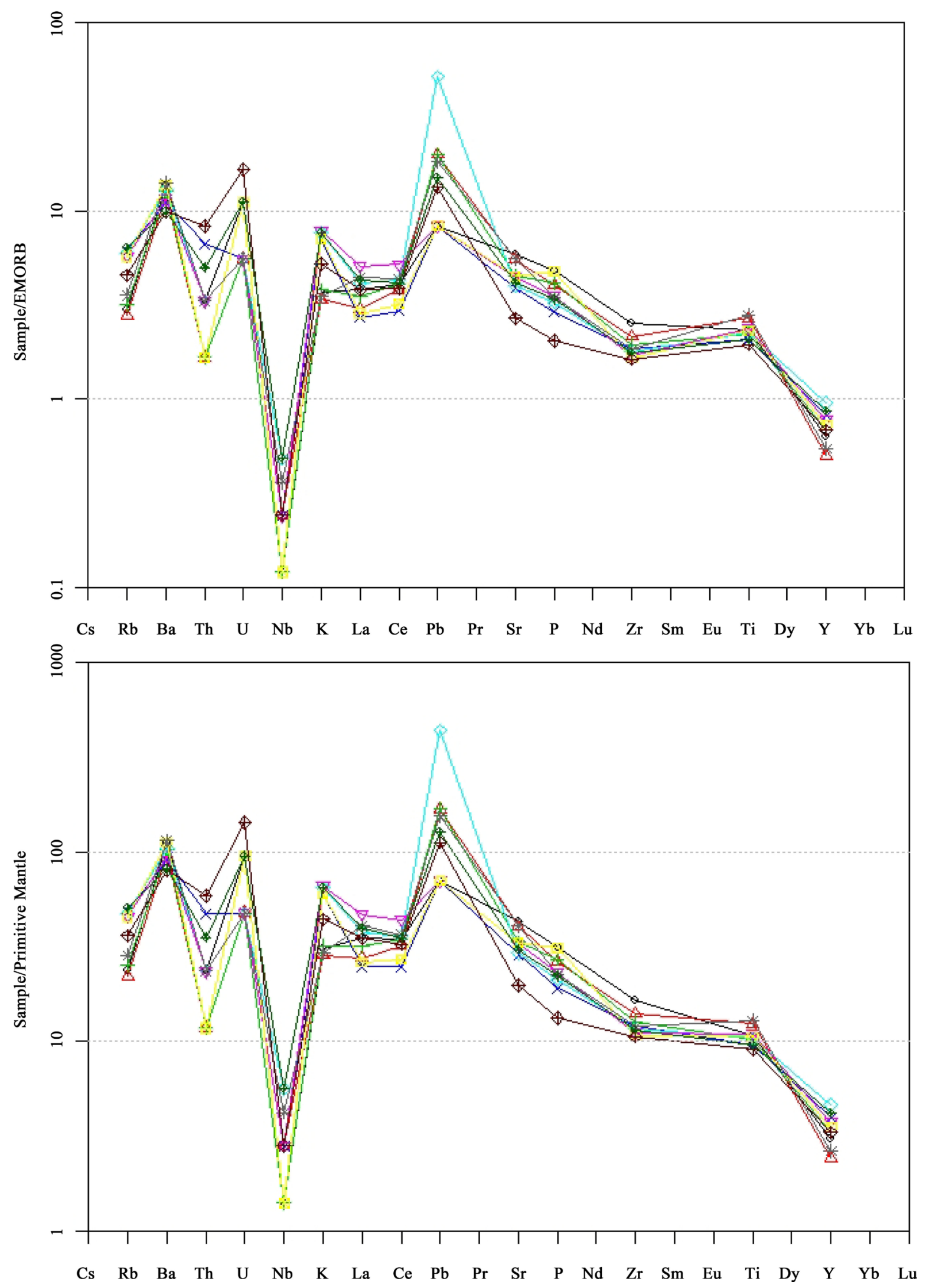

Figure 10. The normalized spider diagram for EMORB and primitive mantle. 
M. A. Arian et al.
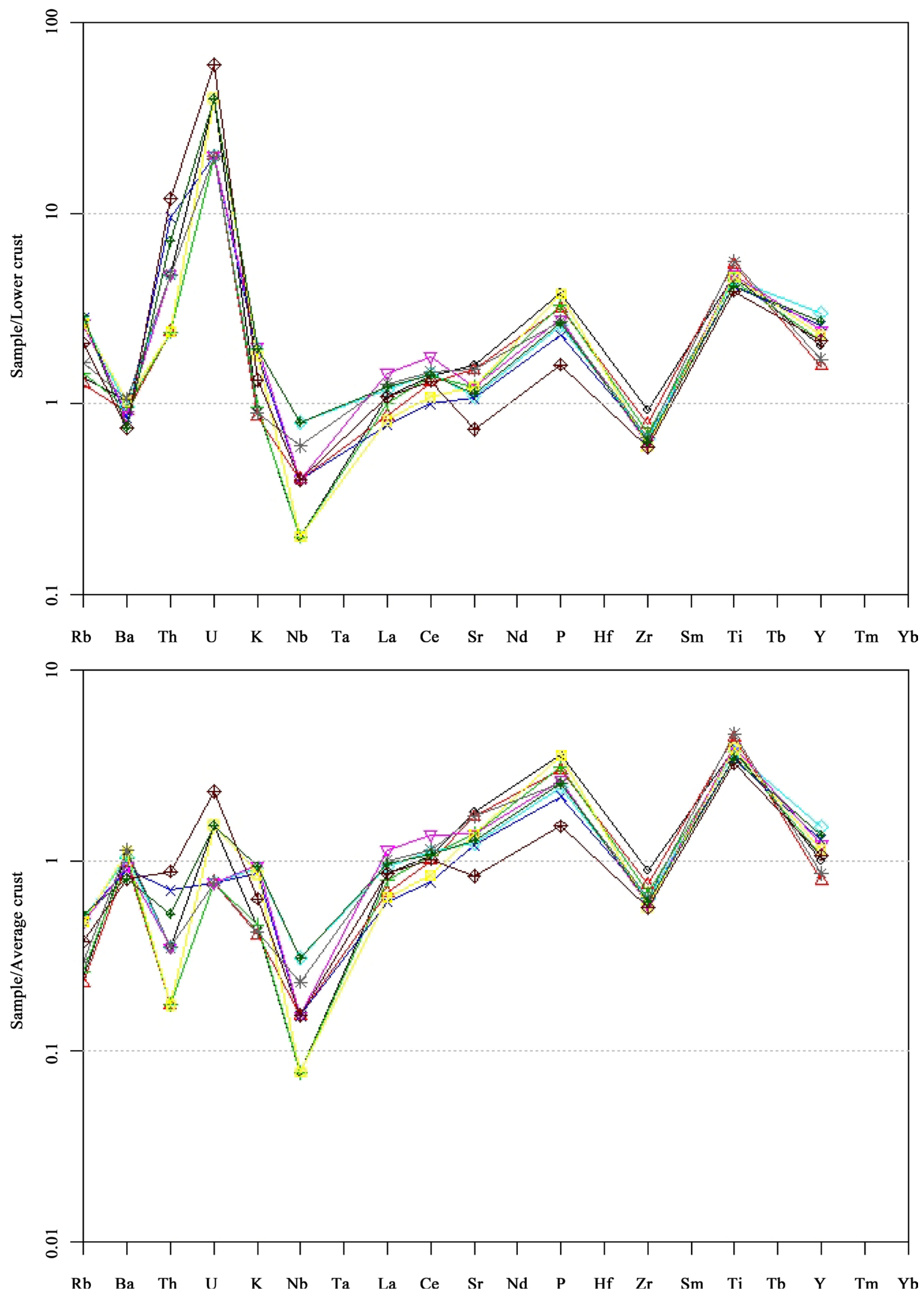

Figure 11. The normalized spider diagram for lower crust and average crust. 

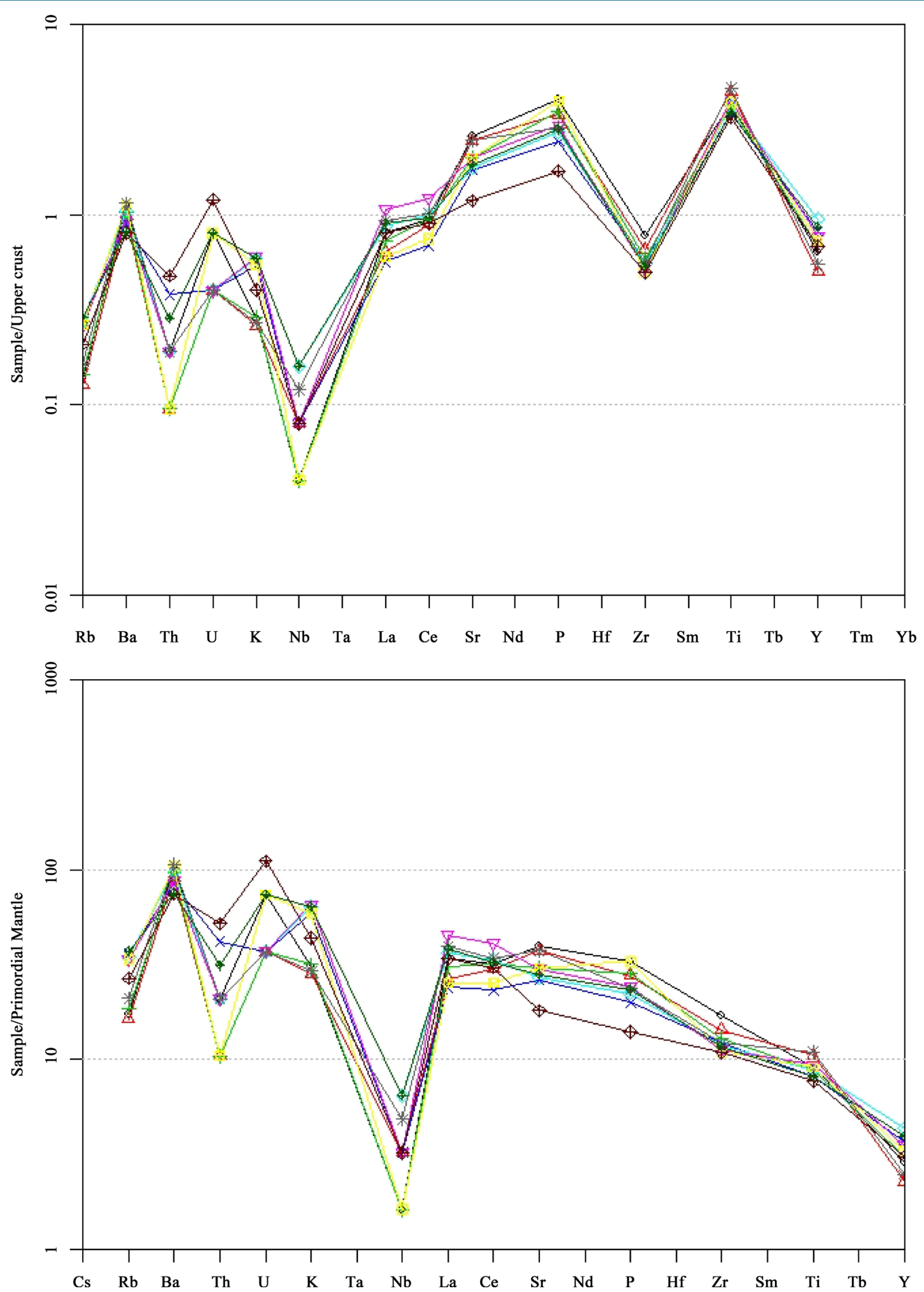

Figure 12. The normalized spider diagram for upper crust and primordial mantle. 


\section{Conclusion}

According to results of analyses, the $\mathrm{SiO}_{2}$ content in samples taken from the Alasht volcanic mass varies from $44.02 \%$ to $50.54 \%$. Also, as has been shown by petrographic studies, this igneous mass consists of olivine basalt, dolerite, gabbro and micro gabbro, and in all collected samples $\mathrm{Na}_{2} \mathrm{O}$ content is higher than $\mathrm{K}_{2} \mathrm{O}$. From ten samples, one is olivine-normative and the rest are instead quartz-normative; meanwhile petrographic studies show that most samples contain olivine, which points to silica-rich matrix of these rocks. According to chemistrybased naming process carried out through TAS method, these rocks are entirely basalt and basic and are all products of a Sub-alkaline-Tholeiitic magma.

\section{References}

[1] Streckeisen, A. (1976) To Each Plutonic Rock Its Proper Name. Earth Science Reviews, 12, 33.

[2] Cox, K.G., et al. (1979) The Interpretation of Igneous Rocks. Allen and Unwin, London, 450 p. http://dx.doi.org/10.1007/978-94-017-3373-1

[3] Middlemost, E.A.K. (1994) Naming Materials in the Magma/Igneous Rock System. Earth-Science Reviews, 37, 215244. http://dx.doi.org/10.1016/0012-8252(94)90029-9

[4] Le Bas, M.J., Le Maitre, R.W., Streckeisen, A. and Zanettin, B. (1986) A Chemical Classification of Volcanic Rocks Based on the Total Alkali-Sillica Diagram. Journal of Petrology, 27, 754-750.

[5] De la Roche, H., Leterrier, J., Grandclaude, P. and Marchal, M. (1980) A Classification of Volcanic and Plutonic Rocks Using R1R2-Diagram and Major Element Analyses-Its Relationships with Current Nomenclature. Chemical Geology, 29, 183-210. http://dx.doi.org/10.1016/0009-2541(80)90020-0

[6] Winchester, J.A. and Floyd, P.A. (1977) Geochemical Discrimination of Different Magma Series and Their Differentiation Products Using Immobile Elements. Chemical Geology, 20, 325-343. http://dx.doi.org/10.1016/0009-2541(77)90057-2

[7] Jensen, L.S. and Pyke, D.R. (1982) Komatiites in Ontario Portion of the Abitibi Belt. In: Arndt, N.T. and Nisbet, E.G., Eds., Komatiites, 147-157. 